\title{
STRATEGI PENINGKATAN KETERAMPILAN MENYIMAK BEREKUIVALENSI TOEFL BAGI SISWA SMA
}

\section{STRATEGIES IN IMPROVING TOEFL-BASED LISTENING SKILL FOR HIGH SCHOOL STUDENTS}

\author{
${ }^{1)}$ Tri Agustini Solihati, ${ }^{2)}$ Asep Rizki Mukti, ${ }^{3)}$ Rudi Permadi \\ ${ }^{1,2,3)}$ Program Studi Pendidikan Bahasa Inggris \\ Fakultas Keguruan dan Ilmu Pendidikan, Universitas Perjuangan Tasikmalaya \\ Jl. PETA No. 177 Kota Tasikmalaya \\ try_leocps@yahoo.co.id
}

\begin{abstract}
ABSTRAK
TOEFL (Test of English as a Foreign Language)merupakan tes yang dilakukan untuk mengukur sejauh mana kemampuan bahasa Inggris seseorang.Tes ini terdiri dari empat jenis kegiatan, yaitu listening comprehension (menyimak), structure and written expression (tata bahasa), reading comprehension (membaca), dan writing (menulis). Pengenalan strategi menyimak diperlukan oleh siswa SMA untuk meningkatkan pemahaman mereka mengenai cara mengerjakan soal menyimak dengan lebih praktis. Namun siswa SMA di Desa Linggaraja ini belum tahu dan belum pernah memperoleh pelatihan semacam ini di sekolah mereka masing-masing.Oleh karena itu, dalam kegiatan pengabdian masyarakat ini siswa tersebut diberikan pengenalan sekaligus pelatihan strategi peningkatan keterampilan menyimak berekuivalensi TOEFL.Materi yang dipaparkan secara khusus membahas strategi menaklukan soal-soal menyimak pada tes TOEFL.Pelatihan ini diselenggarakan di Desa Linggaraja Kecamatan Sukaraja Kabupaten Tasikmalaya yang termasuk wilayah $3 T$ (terluar, terdepan, dan terpencil).Pelatihan ini diikuti oleh 20 siswa SMA, warga Desa Linggaraja.Pelatihan dilaksanakan selama 14 pertemuan inti, yang terdiri dari kegiatan pre-test, 12 strategi menyimak, dan post-test. Hasil kegiatan menunjukkan peserta dapat memperoleh rata-rata nilai 67,4.
\end{abstract}

Kata Kunci : Menyimak, TOEFL Siswa

\begin{abstract}
TOEFL (Test of English as a Foreign Language) is a test conducted to measure the extent of person's English skills. This test consists of four types of activities, they are listening comprehension, structure and written expression, reading comprehension, and writing. The introduction of listening strategies is required for high school students/equivalents to improve their understanding of how to conductlistening questions more practically. However, the high school students in Linggaraja Village have not known yet and they have never received this kind of training in their school. Therefore, in the community service activities conducted by English Education Department of Perjuangan University, the students are given introduction as well as TOEFL competency skills enhancement skills training. So, of course, the material presented specifically deliver the strategy of conquering the listening questions on the TOEFL test. The training was held in Linggaraja Village, SukarajaDistrict, Tasikmalaya Regency, which included (outer, outer, and remote) areas. The training was attended by 20 high school students, villagers of Linggaraja. Training was conducted during 14 core meetings, consisting of pre-test, 12 listening strategies, and post-test. Pre-test and post-test were done only to find out how far they get benefit from the activities.
\end{abstract}

Keywords : Listening, Students' TOEFL 


\section{PENDAHULUAN}

Bahasa Inggris telah menjadi bahasa internasional di berbagai negara termasuk di Indonesia. Sebagai warga negara yang siap dalam menghadapi persaingan global ini, dituntut untuk dapat menggunakan bahasa pengantar yaitu bahasa Inggris sebagai bahasa asing. Dalam dunia pendidikan, bahasa Inggris sudah menjadi bahasa yang wajib selain bahasa daerah dan bahasa Indonesia yang dipelajari.

Untuk itu para siswa harus siap dalam menggunakan bahasa Inggris. Tetapi terkadang dalam belajar bahasa Inggris, mereka memilliki kendala. Untuk itu perlu adanya strategi dalam mempelajari bahasa Inggris. Agar tidak tertinggal dalam mempelajari bahasa Inggris, perlu adanya suatu tindakan agar dapat mengajarkan dan memperkenalkan bahasa Ingris pada masyarakat terutama para siswa Di beberapa daerah salah satunya di Desa Linggaraja, bahwasanya desa ini termasuk salah satu dari 2 desa yang dinyatakan sebagai "desa tertinggal" di Kecamatan Sukaraja, selain Desa Sirnajaya. Adapun jumlah desa yang bearada di kecamatan ini berjumlah 8, yaitu Desa Linggaraja, Desa Sirnajaya, Desa Janggala, Desa Tarunajaya, Desa Marga Laksana, Desa Leuwi Budah, Desa Mekarjaya, dan Desa Sukapura. Jumlah penduduk di Desa ini diperkirakan mencapai 6.573 jiwa.ternyata hanya sebagian kecil saja yang mengenyam bangku pendidikan sampai ke jenjang SMA/ sederajat.Sekitar 30 orang yang sedang bersekolah SMA, dan 12 orang yang sedang melanjutkan studi di perguruan tinggi. Tentu saja kegiatan ini akan juga memberikan gambaran yang nyata mengenai kompetisi dalam dunia pendidikan dan lapangan kerja.

Berdasarkan analisis situasi di atas dapat diidentifikasi bahwa lemahnya perekonomian masyarakat dan lambatnya pembangunan desa menjadi faktor besar terlahirnya desa ini sebagai salah satu desa tertinggal, tentu saja hal ini akan erat kaitannya dengan kesadaran dan keterbatasan masuknya pendidikan. Mereka yang kebanyakan berasal dari keluarga degan kemampuan ekonomi menengah ke bawah, tidak mampu menjangkau biaya pendidikan yang terbilang mahal.Ditambah lagi akomodasi yang tidak mendukung, kegiatan pembangunan infrstruktur jalan yang lamban dan cenderung terbengkalai, jauhnya jarak tempuh untuk SMA terdekat. Sehingga kebanyakan siswa yang sudah lulus jenjang SMP dengan jarak tempuh kurang lebih 2,5 Km lebih diarahkan untuk bekerja seadanya di lingkungan rumah, sebagai operator mesin bordir yang ternyata penghasilannya jauh dari UMR Kabupaten Tasikmalaya. Karena untuk jarak tempuh SMA terdekat akan menempuh jarak $4 \mathrm{Km}$. Jika mereka berjalan kaki, tentu saja mereka akan sudah kelelahan setibanya di sekolah. Selain itu ditengah-tengah tuntutan penguasaan Bahasa Inggris yang terus meningkat, berbanding negative dengan penguasaan mereka terhadap Bahasa asing tersebut.Apalagi jika sampai dihadapkan pada realita bahwa persyaratan melamar pekerjaan atau melanjutkan studi perlu didukung dengan pengusaan Bahasa Inggris yang terbukti dengan adanya sertifikat TOEFL.Mereka sudah tidak lagi memiliki pilihan, selain putus sekolah.

Pada kegiatan pengabdian sebelumnya, yaitu di Bulan Desember 2016, 15 orang siswa sudah memperoleh pengenalan Bahasa Inggris berekuivalensi TOEFL. Para peserta pelatihan begitu antusias mengikuti kegiatan pelatihan.Hal ini disimpulkan dari kedisiplinan mereka selama mengikuti kegiatan.Karena indikator keberhasilan yang ditentukan pada kegiatan tersebut adalah kehadiran 
pada saat pelatihan dan simulasi tes.Terbukti seluruh peserta menghadiri ke2 kegiatan tersebut dengan baik.Oleh karena itu, hal tersebut sudah menunjukkan bahwa mereka pun berkeinginan keras untuk dapat menguasai Bahasa Inggris. Namun pada umumnya mereka masih memiliki penguasaan bahasa Inggris yang rendah, yaitu 5 diantaranya berada pada tingkat menengah bawah, 9 diantaranya berada pada tingkat dasar, dan 1 peserta memiliki kemampuan yang kurang dari kriteria tingkat dasar. Sedangkan skor 480520 dengan kategori menengah ke atas merupakan batasan yang cukup baik sebagai cerminan kemampuan bahasa Inggris seseorang untuk berbagai tujuan; melanjutkan studi, memperoleh beasiswa, bahkan untuk memperoleh pekerjaan.Maka mereka pun begitu berharap jika kegiatan ini dapat dilanjutkan dengan kursus singkat yang lebih intensif.Apalagi secara psikologis, pada dasarnya mereka memiliki potensi untuk bisa diarahkan lebih baik pada penguasaan bahasa Inggris.

TOEFL merupakan kependekan dari Test of English as a Foreign Language, yang merupakan ujian yang dilakukan untuk mengukur sejauh mana kemampuan bahasa Inggris seseorang. Tes ini digunakan untuk keperluan mendaftar ke lembaga pendiidkan di Amerika Serikat maupun di negara lain. Tes ini diambil oleh pendaftar yang bahasa ibunya bukan bahasa Inggris.Tes ini pertama kali dilaksanakan pada tahun 1963 dan telah diikuti oleh jutaan orang di seluruh dunia.

Menurut Pratiwi, dkk(2012), dalam tes TOEFL, ada empat bagian yang diujiankan, yaitu listening comprehension (mendengarkan), structure and written expression (tata bahasa), dan reading comprehension (membaca), dan writing (menulis). Pada bagian listening comprehension, ada 50 soal percakapan dengan alokasi waktu 40 menit.Pada bagian structure and written expression, ada 40 soal dengan alokasi waktu 25 menit.Pada bagian reading comprehension, ada 50 soal bacaan dengan alokasi waktu 55 menit.Sedangkan untuk bagian writing, tiap peserta diberikan waktu 30 menit untuk menulis esai yang berisi tentang opini pribadi mengenai suatu topik.

Dalam TOEFL sebenarnya hanya ada tiga bagian pertama yang disebutkan di atas, yaitu bagian listening comprehension, structure and written expression, dan reading comprehension.Bagian writing merupakan bagian yang nilainya terpisah dari TOEFL.Bagian ini diselenggarakan oleh pihak TOEFL dengan TWE (Test of Written English). Selain TWE, ada juga tes lain yang dilakukan terpisah dari TOEFL.

Ada dua jenis TOEFL yang bisa diikuti, yaitu IBT (Internet Based Test) dan PBT (Paper Based Test).IBT merupakan jenis TOEFL yang dilakukan secara online dengan menggunakan komputer.Pada awalnya, jenis ini dinamakan CBT (Computer Based Test), namun sekitar tahun 2005 diganti dengan istilah IBT. Kebalikan dari jenis IBT yang menggunakan komputer, TOEFL jenis PBT menggunakan cara manual, yaitu menjawab soal dengan kertas dan pensil 2B. Selain itu, perbedaan yang paling mendasar dari kedua jenis TOEFL ini adalah penilaian skor akhirnya.Skor PBT berkisar antara 310-667, sedangkan skor IBT berkisar antara 0-120.TOEFL sendiri sudah beberapa kali mengalami penyempurnaan oleh lembaga penyelenggaranya, ETS. Bentuk-bentuk TOEFL Test yang pernah diperkenalkan ke publik yaitu :

a. TOEFL Paper Based Test

Terdiri atas 3 section : Listening,

Structure, and Reading

Maximum Score : 677

b. TOEFL Computer Based Test

Terdiri dari 4 Section : Listening, Structure, Reading, Writing

Maximum Score : 300

c. TOEFL Internet Based Test 
Terdiri dari 4 section : Listening, Reading, Writing, Speaking.

Maximum score : 120 .

Dari keempat jenis kemampuan TOEFL, yaitu kemampuan menyimak atau mendengarkan (listening comprehension) merupakan salah satu kemampuan yang diujikan di dalam tes TOEFL, untuk itu perlu diterapkan strategi dalam menyimak atau mendengarkan.

Menyimak memiliki makna mendengarkan atau memperhatikan dengan seksama apa yang dikatakan orang lain atau mendengarkan suatu percakapan dari media. Menyimak didefinisikan sebagai suatu aktivitas yang mencakup kegiatan mendengar suatu bunyi bahasa, mengidentifikasi, dan memberikan respon atas makna yang terkandung dalam bahan suatu percakapan. Seperti yang diungkapkan oleh pendapat Tarigan (1994) , "Pada kegiatan mendengar mungkin si pendengar tidak memahami apa yang didengar. Pada kegiatan mendengarkan sudah ada unsur kesengajaan, tetapi belum diikuti unsur pemahaman karena itu belum menjadi tujuan." Kegiatan menyimak mencakup mendengar, mendengarkan, dan disertai usaha untuk memahami apa yang disimaknya. Dalam kegiatan menyimak ada unsur kesengajaan, perhatian dan pemahaman, yang merupakan unsur utama dalam setiap peristiwa menyimak. Oleh karena itu menyimak adalah suatu proses kegiatan mendengarkan suatu pesan dengan seksama, penuh pemahaman, apresiasi, serta interpretasi untuk memperoleh informasi, menangkap isi, serta memahami makna komunikasi yang disampaikan oleh si pembicara melalui ujaran atau bahasa lisan.

Berdasarkan pengertian yang sudah diuraikan diatas maka dapat disimpulkan bahwa menyimak adalah suatu proses kegiatan mendengarkan suatu pesan yang berbentuk atau pemikiran secara lisan dengan seksama untuk memperoleh informasi atau makna yang disampaikan oleh pembicara atau melalui media.

Ada empat macam aspek keterampilan berbahasa. Keempat aspek keterampilan tersebut meliputi keterampilan menyimak, keterampilan berbicara, keterampilan membaca, dan keterampilan menulis. Keempat keterampilan ini tidak dapat dipisahkan satu sama lain. Dengan demikian keterampilan menyimak sangat memegang peranan dalam proses interaksi berbahasa seseorang, karena baik bahasa lisan maupun bahasa tulisan diperoleh.

Faktor-Faktor yang mempengaruhi kegiatan menyimak menurut Tarigan (1994) adalah sebagai berikut:

1. Kondisi fisik seseorang. Menyimak merupakan faktor penting yang turut menentukan keefektifan serta kualitas dan kuantitas menyimak.

2. Faktor psikologis yang mempengaruhi proses menyimak. Faktor psikologis yang positif memberi pengaruh yang baik, sedangkan faktor psikologis yang negatif dapat memberi pengaruh yang buruk pula terhadap kegiatan menyimak.

3. Faktor pengalaman. Sikap merupakan hasil pertumbuhan dan perkembangan pengalaman. Kurangnya minat merupakan akibat dari pengalaman yang kurag atau tidak sama sekali pengalaman dalam bidang yang disimak.

4. Faktor sikap. Pada dasarnya manusia hidup mempunyai sikap utama mengenai segala hal, yaitu sikap menerima dan sikap menolak.

5. Faktor motivasi. Motivasi merupakan salah satu butir penentu keberhasilan seseorang. Jika motivasi kuat untuk mengerjakan sesuatu maka dapat diharapkan orang itu akan berhasil mencapai tujuan. Begitu pula halnya dengan menyimak. 


\begin{abstract}
Berdasarkan pendapat tersebut maka dapat disimpulkan bahwa faktor-faktor yang mempengaruhi kegiatan menyimak meliputi kondisi fisik, faktor psikologis, faktor pengalaman, faktor sikap, dan faktor motivasi.
\end{abstract}

Menurut Tarigan (1994), faktor-faktor penting dalam menyimak adalah sebagai berikut:

1. Membedakan antar bunyi fonemis.

2. Mengingat kembali kata-kata.

3. Mengidentifikasi tata bahasa dari sekelompok kata.

4. Mengidentifikasi bagian-bagian pragmatik, eskpresi, dan seperangkat penggunaan yang berfungsi sebagai unit sementara mencari arti/makna.

5. Menghubungkan tanda-tanda linguistik ke tanda-tanda para linguistik (intonasi) dan ke nonlinguistik (situasi yang sesuai dengan objek supaya terbangun makna, menggunakan pengetahuan awal (yang kita tahu tentang isi dan bentuk dan konteks yang telah siap dikatakan untuk memperkirakan dan kemudian menjelaskan makna.

6. Mengulang kata-kata penting dan ideide penting.

Strategi pembelajaran sebagai sebuah perencanaan yang berisi tentang rangkaian kegiatan yang didesain untuk mencapai tujuan pendidikan tertentu. Menurut Uno (2009)pengertian strategi pembelajaran adalah, Cara-cara yang akan digunakan oleh pengajar untuk memilih kegiatan belajar yang akan digunakan selama proses pembelajaran. Pemilihan tersebut dilakukan dengan mempertimbangkan situasi dan kondisi, sumber belajar, kebutuhan dan karakteristik peserta didik yang dihadapi dalam rangka mencapai tujuan pembelajaran tertent.Menurut Wina (2006) pola umum perbuatan guru-peserta didik di dalam perwujudan kegiatan belajar-mengajar. Sifat pola umum maksudnya jenis dan urutan perbuatan yang dimaksud nampak dipergunakan dan/atau dipercayakan guru-peserta didik di dalam bermacam-macam peristiwa belajar.

Berdasarkan uraian tersebut dapat disimpulkan bahwa strategi pengajaran yaitu pemilihan cara dalam kegiatan mengajar yang melibatkan siswa. Pemilihan tersebut dilakukan dengan mempertimbangkan situasi dalam pembelajaran dan kondisi peserta didik yang dihadapi dalam rangka mencapai tujuan pembelajaran yang efektif dan efisien.

Sanjaya (2006) mengemukakan tujuh jenis strategi pembelajaran yang sesuai dengan tuntutan standar proses pendidikan, yaitu:

1. Strategi Pembelajaran Ekspositori, dengan strategi ini guru bercerita, berceramah atau bertutur guna menyampaikan konsep, ide, gagasan dan keyakinannya kepada peserta didik. Strategi ini pada dasarnya berfokus pada guru, guru harus bijak dalam mengendalikan proses agar tujuan belajar tercapai.Strategi Pembelajaran Ekspositori lebih banyak menuntut guru dalam menyampaikan pembelajaran sedangkan siswa hanya menerima apa yang disampaikan oleh guru.

2. Strategi Pembelajaran Inkuiri, dalam strategi ini guru ialah sebagai fasilitator, penuntun dan rekan kerja, dengan demikian gurulah yang memotivasi peserta didik dalam proses belajar agar mereka mencari dan menemukan gagasan.Pembelajaran dimulai dengan memberikan penjelasan berupa topik dan menuntun siswa untuk terlibat dan pada akhirnya menarik kesimpulan.

3. Strategi Pembelajaran Berbasis Masalah, menekankan pada pengenalan masalah agar dapat memahami (analisis), perumusan langkah penyelesaian, pengujian data atau informasi, dan penyimpulan. 
4. Strategi Pembelajaran Peningkatan Kemampuan Berpikir (SPPKB), menekankan pembentukan kemampuan berpikir peserta didik. Guru menuntun murid bukan hanya untuk mengetahui isi bahan ajar (knowing what), melainkan juga dalam rangka memahami kode belajar dan merumuskan konsep, ide atau gagasan (knowing how).

5. Strategi Pembelajaran Kooperatif (SPK), memiliki asumsi bahwa pengetahuan dibentuk dan dibangun melalui kerjasama dalam aktivitas belajar, termasuk menyelidiki, berdiskusi, memahami dan memecahkan masalah.

6. Strategi Pembelajaran Kontekstual, mengasumsikan bahwa konteks kehidupan sosial dan budaya merupakan sumber serta media belajar yang penuh makna, orang tidak hanya dapat belajar dari membaca buku atau literatur. Strategi juga menekankan konsep belajar konstruksionis, yaitu pengetahuan dibentuk melalui penyelidikan hal-hal yang terjadi di lingkungan (konteks) bukan diberikan sebagai hasil olahan.

7. Strategi Pembelajaran Afektif, menekankan metode pemecahan masalah dan penjelasan atau klarifikasi.

Menurut Mager dalam Uno (2009) dalam bukunya yang berjudul Model Pembelajaran terdapat beberapa kriteria yang dapat digunakan dalam memilih strategi pembelajaran, yaitu sebagai berikut:

1. Berorientasi pada tujuan pembelajaran

2. Tipe perilaku apa yang diharapkan dapat dicapai oleh peserta didik.

3. Pilih teknik pembelajaran sesuai dengan keterampilan yang diharapkan dapat dimiliki saat bekerja nanti (dihubungkan dengan dunia kerja).
4. Gunakan media pembelajaran yang sebanyak mungkin memberikan rangsangan pada indra peserta didik

Dalam keterampilan menyimak ini, diterapkan strategi pembelajaran keterampilan menyimak berekuivalensi TOEFL. Menurut Phillips (2003) ada beberapa teknik dalam mempelajari skill yang ada dalam menyimak yang terdiri dari short conversation (percakapan pendek), long conversation (percakapan panjang), dan ceramah. Diantaranya :

1. Restatement: teknik pemilihan diksi tanpa mengubah makna yang ingin disampaikan.

2. Negatives: teknik mengubah bentuk kalimat yang terdengar dari penutur ke2 dengan konsistensi jenis tenses yang digunakan. Jika kalimat yang disampaikan berpola negatif, maka pilihan jawaban yang tepat akan berbentuk positif. Begitu pun sebaliknya.

3. Suggestion: teknik mengenali variasi jenis ungkapan yang mengandung saran.

4. Passive: teknik penguasaan perubahan kalimat, berdasarkan informasi yang dituturkan oleh pembicara ke-2. Jika kalimat tersebut berpola aktif, maka jawaban yang tepat adalah pada pola pasif. Begitupun sebaliknya.

5. Who and where: teknik menemukan jawaban yang menanyakan "siapa dan dimana" berdasarkan konteks dialog yang dipaparkan. Adapun kunci informasi yang bisa diperoleh, tetap pada penutur ke-2.

6. Agreement: teknik mengenali variasi jenis ungkapan yang mengandung persetujuan.

Phillips (2003) juga menyatakan, strategi yang harus dikuasai pada bentuk percakapan panjang dan ceramah adalah sebagai berikut: 
1. The question: kemampuan mengantisipasi jenis pertanyaan yang muncul berdasarkan pilihan jawaban yang ada adalah langkah yang baik untuk membantu menjawab jenis pertanyaan ini.

2. The topic: pada bagian ini, satu atau dua baris awal dari informasi yang dituturkan adalah tempat terbaik untuk menemukan jawaban soal ini. Karena ide pokok sebuah informasi, seringkali dimunculkan di awal percakapan atau ceramah.

3. The order of the answers: sambil mendengarkan audio, maka kita harus yakinkan bahwa informasi yang dicari akan ditanyakan secara berurutan pada setiap nomer soal.

Berdasarkan pemaparan di atas dapat disimpulkan bahwa tujuan dari strategi ini adalah untuk mempermudah siswa dalam mempelajari bahasa Inggris melalui strategi berekuivalensi TOEFL dengan melatih keterampilan menyimak.

\section{METODE}

Dalam program ini, metode yang digunakan adalah:

1. Metode diskusi, yaitu pemateri dan peserta melakukan dialog yang membahas bagaimana pelaksanaan pembelajaraan Bahasa Inggris yang biasa dilakukan di sekolah masingmasing, khususnya yang berkaitan dengan penguatan keterampilan menyimak.

2. Metode ceramah, yaitu digunakan untuk memaparkan materi yang telah disusun oleh tim pelaksana.

3. Metode tanya jawab dan praktek, yaitu digunakan untuk merespon sejauh mana tingkat pemahaman peserta terhadap materi yang disampaikan melalui soal-soal latihan yang kemudian dibahas secara komprehensif.
Adapun rangkaian pelaksanaan kegiatan dibagi menjadi 16 pertemuan, 12 pertemuan pembelajaran, 1 pertemuan pretest, 1 pertemuan post-test, dilengkapi dengan kegiatan pembukaan dan penutupan. Masing-masing pertemuan dilaksanakan selama 90 menit, tepatnya pukul 16.00-17.30.

\section{HASIL DAN PEMBAHASAN}

Kegiatan yang dilakukan dengan tatap muka dan praktek pada umumnya berjalan lancar sesuai dengan yang diharapkan. Untuk menumbuhkan rangsangan belajar, seluruh peserta diberitahukan terlebih dahulu pandangan secara umum mengenai manfaat menguasai Bahasa Inggris, baik untuk prestasi akademik maupun nonakademik.

Kebanyakan dari mereka memang kurang memiliki ketertarikan belajar Bahasa Inggris, apalagi jika kaitannya dengan kegiatan menyimak yang hampir sulit dipahami, karena dialek dan aksen yang berbeda dari penutur aslinya. Lebih jauh lagi, pembelajaran Bahasa Inggris di kelas diberikan tidak lebih dari 2 jam pelajaran dalam satu pecan. Artinya banyak keterbatasan yang tidak dapat difasilitasi oleh pihak sekolah, kaitannya dengan kebijakan pemerintah pada penetapan kurikulum, sehingga hadirnya kegiatan ini menjadi angin segar untuk mereka. Mereka kembali menemukan ketertarikannya terhadap Bahasa Inggris.

Diawali dengan kegiatan pre-test, sebagai informasi awal atas keterampilan menyimak mereka, siswa diberikan handout berupa 50 soal pilihan ganda berikut lembar jawabannya yang harus diselesaikan dalam waktu 35 menit. Kemudian dilakukan pemeriksaan secara bertukar hingga diperoleh rata-rata nilai 24,7 . Nilai yang cenderung rendahuntuk mereka yang pasti harus melewati mata pelajaran ini pada ujian nasional. 
Berikutnya, dilakukan tanya jawab guna mengumpulkan informasi mengeani kendala-kendala yang sebetulnya mereka hadapi pada saat mengerjakan soal-soal tersebut.

Hampir semua peserta tidak tahu bahwa menyelesaikan soal menyimak dapat dilalui dengan strategi yang tepat.Kebanyakan peserta memilih jawaban dengan indikasi pelafalan pada audio yang cenderung mirip dengan pilihan jawaban yang tersedia.Misalnya pada kata sick dengan thick.Sesuatu yang menjebak tentunya.Dan sayangnya hal tersebut bukanlah langkah yang tepat untuk menemukan jawaban yang benar. Karena pilihan jawabana akan didominasi dengan penyajian kalimat yang berbeda, tanpa mengubah makna yang diperoleh dari audio. Istilah ini kita kenal dengan restatement atau paraphrase.Contoh sick dengan ill, 2 kata yang secara penulisan jauh berbeda namun memiliki makna yang sama. Sehingga mengandalkan bunyi yang mirip adalah sebuah hal yang perlu dicermati.

Pada pertemuan berikutnya, pengenalan, paparan, praktek, dan diskusi yang berakitan dengan strategi menyimak pun disampaikan. Mulai dari mengenali strategi menghadapi soal-soal pada percakapan pendek, diikuti dengan soal pada percakapan panjang, dan ditutup dengan kegiatan menyimak paparan/ceramah.Secara umum, pada percakapan panjang, semua jawaban akan dapat dengan mudah diperoleh hanya dengan memusatkan perhatian pada pembicara ke-2. Sedangkan pada percakapan panjang dan paparan, selalu perhatikan topik yang dibicarakan, jenis pertanyaan, dan susunan jawaban yang disajikan.

Kegiatan pengabdian diakhiri dengan post-test, sebuah kegiatan yang bisa mengukur sejauh mana pemahaman peserta terhadap kegiatan yang sudah dilaksanakan. Setelah dilakukan evaluasi, peserta pengabdian dapat memperoleh ratarata nilai 67,4. Nilai yang cukup baik, walaupun masih perlu pendampingan yang intensif guna mempertahankan ketertarikan dan meningkatkan keterampilan mereka.

Strategi TOEFL merupakan strategi untuk membantu siswa dalam keterampilan menyimak sehingga siswa dapat terlatih keterampilan menyimak mereka. Berdasarkan hasil penelitian yang dilakukan oleh Masyitoh (2016) bahwa proses pembelajaran menyimak berita melalui strategi interaktif mengalami peningkatan. Peningkatan terjadi pada kualitas proses dan produk pembelajaran. Peningkatan secara proses dapat dilihat dari beberapa aspek, yaitu (1) semangat belajar, (2) perhatian terhadap proses pembelajaran, (3) keaktifan, (4) proses belajar. keterampilan menyimakberita siswa kelas X-6 SMA Negeri 2 Banguntapan, Bantul telah mengalamipeningkatan baik proses maupun hasil setelah menggunakan strategi interaktif Begitu juga dengan strategi TOEFL yang diterapkan pada siswa dalam keterampilan menyimak.

Kegiatan ini akan dilanjutkan pada tahapan berikutnya, yaitu strategi menaklukkan soal structure and written expression berbasis TOEFL.Kegiatan yang tentunya sudah sangat dinantikan oleh mereka.

\section{SIMPULAN}

Kesimpulan dari kegiatan pengabdian ini adalah bahwa dengan memberikan pengenalan strategi menyimak, siswa SMA/peserta pengabdian dapat lebih mudah menyelesaikan soal-soal listening berekuivalensi TOEFL. Selain itu gairah dan motivasi mereka untuk mempelajari Bahasa Inggris semakin meningkat.Nampak sekali dari keseriusan dan kedisiplinan mereka selama mengikuti kegiatan yang diprogramkan. 
DAFTAR PUSTAKA

Masyitoh, (2016). Peningkatan Keterampilan Menyimak Berita Melalui Strategi Interaktif Pada Siswa Kelas X SMA Negeri 2 Banguntapan. PBSI FBS UNY dari

http://journal.student.uny.ac.id/ojs/ index.php/pbsi/article/viewFile/87 $29 / 8383$

Phillips. D., (2003). Longman introductory course for the TOEFL Course.The Paper Test.
Pratiwi, A, dkk. (2012). 100\% Best Guide to TOEFL. Jakarta: Laskar Aksara

Wina. S., (2006). Strategi Pembelajaran. Bandung: Kencana Prenada Media Group

Tarigan, H. G. (1994). Menyimak sebagai Suatu Keterampilan Berbahasa. Bandung: Angkasa

Uno, H. B. (2009). Model Pembelajaran. Jakarta: PT. Bumi Aksara 